\title{
DOSSIER
}

\section{A CIEN AÑOS DE LA CONSTITUCIÓN DE 1917: NUEVAS APROXIMACIONES}

Con este dossier la revista Historia Mexicana demuestra fidelidad a sus orígenes y convicciones y continua el reciente ciclo de números conmemorativos de los procesos más significativos de la historia mexicana, todos ellos con profundos impactos internacionales. Es un hecho que desde su nacimiento, hace ya 65 años, Historia Mexicana puso atención a la historia nacional; esto es, a los siglos XIX y Xx. Su postura fue inmediatamente cuestionada por varios colegas de otras instituciones, quienes alegaron que eran historias, sobre todo la del siglo $\mathrm{xx}$, demasiado cercanas para ser vistas con la "neutralidad" necesaria y con la perspectiva adecuada. En efecto, desde sus primeros números fueron considerables los artículos que tuvieron por tema la revolución mexicana. Incluso puede decirse, enfocando el punto, que han sido varios los artículos publicados que tienen como objetivo a Venustiano Carranza y a la Constitución de 1917. Consignemos algunos ejemplos. Para comenzar, en el segundo número de la revista, todavía en el año fundacional 
de 1951, se publicó un trabajo del escritor estridentista Germán List Arzubide, titulado "La rebelión Constituyente de 1917". Posteriormente se publicaron dos artículos sobre la influencia del jurista porfiriano Emilio Rabasa en los congresistas de Querétaro, uno de Hilario Medina (en el núm. 38) aparecido en 1960, y el otro de Charles Hale, viejo amigo de la casa (núm. 189) publicado casi cuarenta años después. Asimismo, en 1973 (núm. 87) se publicó un trabajo de un prestigiado colega norteamericano, Peter Smith, sobre el nivel socioeconómico y educativo de los diputados constituyentes. Por si esto fuera poco, también apareció un artículo (núm. 153) sobre uno de los temas más característicos de la Constitución, el del régimen de trabajo, escrito por Moisés González Navarro, nuestro colega por 50 años. Por lo que toca a Venustiano Carranza, basta recordar la publicación de un artículo de nuestra colega Berta Ulloa sobre el armamento estadounidense en la revolución mexicana (núm. 66), otro de Marina Zuluaga sobre las relaciones diplomáticas españolas; y otro sobre el Poder Legislativo y Carranza (núm. 202), de Ignacio Marván, y dos del biógrafo de Carranza, Douglas W. Richmond, publicados en 1976 y 1982 (núms. 101 y 125, respectivamente).

En cuanto a números de la revista conmemorativos, éste debe verse como la continuidad con los dedicados al impacto en América de la crisis de la Monarquía Hispánica en 1808, y al bicentenario de la Independencia y al centenario de la Revolución, publicados en 2008 y 2010 sucesivamente (núms. 229, 233, 237 y 238). En este sentido, el buen juicio del director de la revista propició la preparación de este dossier sobre la Constitución de 1917, el principal documento de la historia moderna y contemporánea de México, aunque 
puede suponerse que seguirá siendo nuestro principal documento nacional a corto y mediano plazo por lo menos.

La amplitud y complejidad del tema, y el abultado número de colegas interesados en él, sobre todo en este año de aniversario, permitía la inclusión de varios artículos. Sin embargo, enfrentábamos un obstáculo invencible: la dimensión de la revista Historia Mexicana, la que por respeto a sus lectores y tradiciones, no podía permitir la publicación de todo un número dedicado a la Constitución de 1917, pues el compromiso con todos los periodos de la historia mexicana es insalvable.

Así, se acordó publicar un dossier con cuatro artículos, confiados en que los múltiples intereses sobre el tema de la Constitución de 1917 encontrarán cobijo en otros espacios editoriales. El primer artículo, titulado “¿Por qué, cuándo, cómo y quiénes hicieron la Constitución de 1917?”, de quien esto escribe, busca demostrar que el Congreso Constituyente fue planeado, organizado y controlado por un grupo de colaboradores cercanos a Carranza, siendo un mito historiográfico el supuesto dominio obregonista. El siguiente artículo, "La integración del Congreso Constituyente de 1916-1917”, de Juan Bernardino Sánchez Aguilar, busca analizar un tema menospreciado por la historiografía: el de la 'discusión de credenciales' de los diputados constituyentes, pues por lo general los estudiosos se limitan a los debates propiamente legislativos, sin reparar en que en la discusión de credenciales pueden encontrarse las alianza y animosidades que luego definirían la marcha del Congreso. En seguida se publica un trabajo de la reconocida experta en la XXVI Legislatura, Josefina Mac Gregor, precisamente sobre el esencial grupo de los diputados 
“renovadores”, quienes transitaron del maderismo de 1912 al carrancismo de 1916 y 1917. Por último, el dossier concluye con el trabajo del prestigiado politólogo e historiador José Antonio Aguilar Rivera, sobre un tema tan importante como desconocido: las críticas de los juristas y políticos porfirianos - en este caso del mejor de ellos, Emilio Rabasa- a la recién promulgada Constitución de 1917.

El análisis de estos cuatro trabajos seguramente despertará en los lectores el interés por otros temas vinculados al congreso constituyente de Querétaro. Así me sucedió a mí, pero el tamaño de la revista me impidió buscar colegas que los desarrollaran. De hecho, el número no se conformó mediante el procedimiento de las invitaciones, sino con la llegada de tres artículos anónimos vinculados por el tema. Una vez dictaminados positivamente, y luego de ser corregidos, el director de la revista me propuso que los organizara en forma de dossier. Repito que su lectura generó nuevos intereses sobre el tema, los que consigno con la esperanza de que algunos colegas o alumnos compartan mi interés y procedan a analizar dichos temas. Para los interesados en la historia de la prensa seguramente resultará interesante constatar que las diferencias entre las crónicas de El Demócrata y de El Universal son tan grandes, que de ellas podrían reconstruirse dos congresos constituyentes absolutamente distintos. Para los interesados en las similitudes y diferencias entre las facciones maderista y carrancista, seguramente será de interés comparar las reformas que se planteaban en 1912 con las que se propusieron en 1916 y 1917 . Asimismo, considero fundamental que se estudie el impacto que tuvo la presencia de la Expedición Punitiva en el ánimo de los constituyentes, pues seguramente influyó en el carácter 
nacionalista de nuestra Constitución. Por último, para los interesados en cubrir los temas de nuestra historia que estuvieron prácticamente vedados durante muchos años, las críticas a la Constitución son interesantes y muy actuales.

En efecto, la Constitución de 1917 es un tema que interesa no sólo a los historiadores sino también a todos los que están preocupados por el presente y el futuro de México.

\author{
Javier Garciadiego \\ El Colegio de México
}


